\title{
CONCRETO RECICLADO: ESTUDO E CARACTERIZAÇÃO DAS MATÉRIAS PRIMAS
}

\section{Danilo Costa Trombim ${ }^{1}$ \\ Ivan Franco Portela ${ }^{2}$ \\ Erika Peterson Gonçalves ${ }^{3}$}

Resumo: Não é de hoje que a preocupação com o meio ambiente é assunto debatido em diversos setores de produção de materiais para a construção civil. Afinal, este é o setor que mais desperdiça na utilização dos recursos naturais. Simultaneamente, construtoras de diversas regiões do país estudam e desenvolvem metodologias para a execução de empreendimentos com o menor nível de desperdício possível, seja no âmbito ambiental ou econômico, adotando um sistema de gerenciamento de resíduos. Partindo dessa premissa, este estudo busca uma metodologia para o reaproveitamento destes resíduos para revelar, hipoteticamente, a necessidade de se aumentar a porcentagem do cimento para a produção de um concreto com agregado graúdo reciclado mais eficiente e traçar um paralelo entre os dois tipos (concreto convencional e concreto reciclado), verificando assim, até quando o concreto reciclado pode ser considerado mais viável, economicamente.

Palavras-chave: Agregado graúdo; Resíduo da Construção Civil; Concreto reciclado; Concreto estrutural; Agregado reciclado.

\footnotetext{
${ }^{1}$ Engenharia Civil/Universidade do Vale do Paraíba, Brasil. E-mail: costatrombim@hotmail.com.

2 Engenharia Civil/Universidade do Vale do Paraíba, Brasil. E-mail: ifportela@hotmail.com.

${ }^{3}$ FEAU/Universidade do Vale do Paraíba, Brasil. E-mail: erika@univap.br.
} 